\title{
The Study of Organization Development and Regional Bank Changing in Indonesia
}

\author{
Sitti Raha Agoes Salim (Corresponding author) \\ Faculty Economic and Business, Universitas Sumatera Utara \\ j1. Prof. T.M. Hanafiah Campus USU, Medan 20155, Indonesia \\ Tel: 62-81-161-9416 E-mail: sittisalim@yahoo.com
}

\begin{abstract}
Yulinda
Faculty Economic and Business, Universitas Sumatera Utara

j1. Prof. T.M. Hanafiah Campus USU, Medan 20155, Indonesia

'Tel: 62-813-9607-9879 E-mail: yulinda_muchtar@yahoo.co.id
\end{abstract}

\begin{abstract}
Khaira Amalia Fachrudin
Faculty Economic and Business, Universitas Sumatera Utara, Medan, Indonesia,

j1. Prof. T.M. Hanafiah Campus USU, Medan 20155, Indonesia
\end{abstract}

Tel: 62-812-646-9475Ｅ-mail: khairaamalia@yahoo.co.id

Received: August 21, 2014 Accepted: November 14, $2014 \quad$ Published: February 1, 2015

doi:10.5296/jmr.v7i2.6956 URL: http://dx.doi.org/10.5296/jmr.v7i2.6956

\begin{abstract}
The existence of Regional Bank in every province in Indonesia is increasing and getting stronger which support the formation of Regional Development Bank Assosiation (RDBA) /Asosiasi Bank Pembangunan Daerah (Asbanda). There are some facts phenomenon happen on the Regional Bank found through RDBA, such as: limited capital, low brand awareness, innovation and lack of human resource competence. Making a study and discussing the direction of the organization development and the changing which is done by the Regional Bank in Indonesia is the purpose of this research. Quantitative and qualitative data collection method are being used to get the data needed followed by doing descriptive analyzing and
\end{abstract}




\section{Macrothink}

Journal of Management Research

ISSN 1941-899X 2015, Vol. 7, No. 2

focus group discussion to know the changing that happen on the Regional Bank. The summary of the research findings are: there is a changing on the purpose, structure, culture and human resource so the Regional Bank will be able to increase its core capital, enlarge the society brand awareness, apply some innovations in banking system and also proffesional human resource. This finding could be used as the guidance for other Regional Banks which haven't done a changing to be able to increase the competitive advantage in facing the ASEAN Economic Community 2015.

Keyword: Organization Development, Regional Bank, Changes 


\section{Introduction and Research Problem}

In the competition of the finance institution in the knowledge era, the contribution of banking service becomes more complex because it is demanded to give a first-class service in the need of society financial needs, to fulfill the variety of social needs which keeps rising fast, the banking industry performer is demanded to be able to compete in trying to reach the performance accomplishment. The accomplishment from banking sector shows the stronger and healthier ability and contribution, this condition is need to run the economy development in Indonesia, which can be perankan by the national bank, swasta bank, or even regional bank.

The existence of Regional Bank which grows stronger can be seen through the existence of the Regional Development Bank Assosiation (RDBA) /Asosiasi Bank Pembangunan Daerah (Asbanda), some phenomenon facts faced by the Regional Bank are found through Asbanda. Based on the condition above Asbanda as the representative of Regional Bank which formerly known as Regional Development Bank (RDB) formulates a vision of RDB development across Indonesia to become the terkemuka bank in each regions through enrichment of some products and services dengan tajuk Bank Regional Champion (BRC), which set some references standard that can be implented by Regional Bank until year 2014 (Asbanda, 2010). Among the established phenomenons the condition of the achievement of some Regional Bank aspects which is from the financial and non-financial perspecitives can be seen on Table 1.1 


\section{Macrothink}

Table 1.1. The Condition of Regional Bank from some Financial and Non-financial Perspectives

\begin{tabular}{|c|c|c|c|}
\hline No & Description & $\begin{array}{l}\text { Average Achievement in } \\
2010\end{array}$ & 2014 Recommendation \\
\hline 1. & Core Capital & Rp.827,1 Billion & Minimum Rp. 1 Zillion \\
\hline 2. & $\begin{array}{l}\text { The quality and competence } \\
\text { of Human Resources }\end{array}$ & $\begin{array}{l}\text { The response and } \\
\text { anticipation haven't } \\
\text { reached the market standard } \\
\text { The enrichment of the } \\
\text { human resource is not } \\
\text { optimum enough } \\
\text { The performance is } \\
\text { disturbed/hampered }\end{array}$ & $\begin{array}{l}\text { Develop the human } \\
\text { resource. } \\
\text { Develop the working } \\
\text { ethics. } \\
\text { Develop the training } \\
\text { centre }\end{array}$ \\
\hline 3. & $\begin{array}{l}\text { The innovation and } \\
\text { development of the product }\end{array}$ & $\begin{array}{l}\text { The Product and Service } \\
\text { are less competitive }\end{array}$ & $\begin{array}{l}\text { Develop the feature of } \\
\text { the product }\end{array}$ \\
\hline 4. & The office network service & $\begin{array}{l}\text { The sale is not optimum } \\
\text { enough } \\
\text { Limited penetration }\end{array}$ & $\begin{array}{l}\text { Develop the e-banking } \\
\text { Enlarge the delivery } \\
\text { channel }\end{array}$ \\
\hline 5. & Brand awareness & $\begin{array}{l}\text { Product and service are less } \\
\text { interested } \\
\text { The capacity of competence } \\
\text { is ran down } \\
\text { The performance is } \\
\text { hampered }\end{array}$ & $\begin{array}{l}\text { Doing repositioning to } \\
\text { corporate image of } \\
\text { Regional Development } \\
\text { Bank }\end{array}$ \\
\hline
\end{tabular}

Source: Asbanda, (2010)

From Table 1.1 can be known the position of some aspects of Regional Bank in 2010, and recommendation as the purposes in the last of 2014, as capability of every Regional Bank to position ownself in keeping tight competition, with awareness of bigger and wider role and the function of Regional Bank in the future. In other side, there is a real challange which is and will be facing of Regional Bank that is globlalisation and the implementation of ASEAN Economic Society in 2015. While Regional Bank is expected to be able to fix itself and heave a role, not become spectator. From some phenomenons and recommendations which are concluded Regional Bank through Asbanda, can be seen there is effort in organization development intervention. The purpose of this research is to do study in organization development concept and revolution which happen in Regional Bank. The prediction of senior Indonesian Bank researcher makes execelled 6 (six) Regional Banks as Regional Bank Champion in 2014 is Bank Sumut, Bank DKI, Bank Jatim, Bank Jateng, Bank jabar, Bank Kaltim ( Amien, 2012). From the nominated Bank, will be done a study of how is the process done in achieving recommendation which become target in 2014. 


\section{Literature Review}

The existence of organisation today cannot be separated with the environmental change which happen in all aspects, which is on going fast and continuing, the organisation is expected can see the happening revolution around it and capability in evaluating the suitable adaptable need. The clear organization quickly response the happening revolution around it in internal and external. The activity of organization on doing an adaption through the change is called an organization development. The application of organization development has been known since 1930s by the psychologist in realizing the structure of organization in a process to stimulate and motivate the worker. (www.medupenn.edu, 2014.)

The development of the OD theory can be viewed from the two side of view which are old theory and new theory. There is a different emphasizing if is viewed in the definition of the two side of view. The definition of OD in the old of view called OD as an effort to plan the organization in wholely and managed it to increase the effectiveness and the life's organization activity through the intervention which is planned in the process of organization through the behavioral knowledge. ( Beckhard, 1969). In adapting the organization with the environmental revolution which is on going quickly, it appears some of view which have a new meaning about OD, those are OD as an effort to stimulate the member of organization to expand the independent of each member, give a view to the organization based on the experience that they have in the organization and take apart of bigger responsibility for the act that should have been as the member of organization. (Neilsen, 1984). The definition that has been told is parallel with the definion as belows; the development of organization is a system, and also the wide application from the behavioral knowledge in planning and the reinforcement of organizations' strategy, structural, and the process in the increasing of organization's effectiveness. From the investigation of Cumming and Worley (2007), they give a classification to the meaning of OD from the premise/concept/definition that have been told, with the different emphasizing, those are: Burke's give a description which is focused to the attention for culture as the target of the changes, the definition of Frenc's OD is concentrated to long period by using the consultant, the different view that has been told by Beckhard's and Beer's which define OD as a process. Furthermore, from the different partner Burke's dan Bradford's define in wider through the distance and the importance of OD.

Based on the statement above OD is complex because it has varieties of definitions including OD is a study which analyze the theory, and the application to develop the study and effectiveness of human to reach a better achievement in the organization and performance change. From the different view OD is a process of diagnose which happens continuously, then is continued with making plan, implement and evaluate it, with a purpose to transfer the knowledge and skill to fellow organization members to raise the capacity in solving problem and change management in the future. The main point of OD is as a system of changes planning which can be viewed from some perspectives in the activity of organization plan in a large scale, an activity which is showed with the involvement of top management, the improvement of the effectiveness and the health of the organization, the planning implementation, using the behavioral knowledge (Rouda, Kusi, 1996). Then they stated that Action Research as a process which provides model for many of OD intervention, one of the 
important steps in OD which shows many types of activities that can be done by vary organization members. The steps of OD as a process (Sulivan, Lean, 1995), consist of Entry which is concluding the needs for change by acquiring a decision that is suitable in building the trustworthy in the organization, start-up and contract are steps to identify critical factors in success, reality issues, the network of the process in the organization, to clarify rules for consultant and workers as well as time that is agreed if there is resistance in the organization. Assessment and diagnose as the steps to collect data to get the chance and problem in the organization. Feedback as the step which provides two ways to state what is obtained based on the data analysis, every person can give information and also chance to learn from the result of the assessment process. Action Planning is the step to filter the recommendation from the assessment and to consider the alternative and focus of the implementation to the activity that has a very influential effect of positive changes in the organization. Intervention as the real step to do the process of changing, following the action plan is important in this step. Evaluation as the OD successful step should make a meaningful change in the performance and the efficiency of the people in the organization. The step needs the evaluation procedure to verify a success. Adoption is a step after making changes in the organization continued with the implementation process to make sure the things in the activity have not changed thoroughly becoming commitment to be implemented based on the changes. Separation is an acknowledgment step of the possible of better productivity that can happen to do the other steps, and is continued with the contra productive consultation, a plan is made to further communication to monitor the success of the changes that may be planned as the activity of changes in the future.

The reason of organization starts the changes those are caused by organization realize that there is problem affecting to mission and the health of the education, or the leader of organization has the better step of vision in improving organization. From the reference told, can be seen that in order to focus on one of the OD's interventions, it is very important to comprehend of what step will be done in revolution, so that can be have knowledge and skill and ability based on the concept which will be done. This research focus on Organization Development as a process, which is a cycle that ends when found the result of the development based on the plan. The purpose of this research is to do study in the concept of organization development, and revolution which happen to Regional Bank, by doing view and also discussing the way of OD (organization development ) and chain doing by Regional Bank.

\section{Methods}

The type of this research is done by Regional Bank as a study in financial and non financial perspectives. The population is the whole Regional Bank in Indonesia which the total is 26 banks. The population target is Bank DKI, Bank Jabar, Bank Jateng, Bank Jatim, Bank Sumut dan Bank Kaltim, The technique sampling which is used is census. The research samples are Bank Sumut, Bank DKI, and Bank Jatim. The primary data is collected by giving questionnaires to the customers and employers and also interviewing deeply and focus group discussion with the central leader and divisions of the three banks, and also observing the process on teller customer service bank. 


\section{Data Analysis}

The data analysis is done with deductive comprehension is the comprehension which comes from general event which the truthiness has been believed and ends in special new conclusion. This method is started from learning to the former theory and research, collecting data and making conclusion.

\section{Result and Finding}

The Regional Bank Association (RBA)/Asosiasi Bank Daerah (Asabanda) that has members of the representatives from each Regional Bank in Indonesia has done the steps to make changes of the image of brand of the Regional Bank in Indonesia, referring to the process of organization development which consists of some steps which is started with the Entry to conclude the changing needs of the Regional Bank to make an appropriate decision in building the credibility in the Regional Bank. The RBA has also done the start-up and contract steps which are to identify critical factors to reach the success in the banking process by telling the real condition of the Regional Bank, then is related with the chain of the process and the culture of the organization, as well as to clarify the rules for the consultants and workers and the time consideration that has been agreed if there is a resistance in the organization. In Assessment and diagnose the RBA concludes some problems including the relative capital power that is still limited and is smaller compared to the average of the capital of the average national banking industry, the brand awareness of the society towards Regional Bank is still relatively lower than the convention bank, the limited innovation, the quality and competence of the human resource has not reached the market standard, and the limited network service. In Feedback the RBA gives a space to the Regional Bank to provide the two ways communication to state what has been obtained based on the data analysis, all of the human resources in the Regional Bank can contribute information as well as chance to learn from the assessment process. Action Planning is a step where each Regional Bank is given freedom to filter the recommendation from the assessment and to consider the alternative and the implementation focus towards the activity that has positive influential effects to the Regional Bank. Intervention shows the real step that is done by each Regional Bank in implementing the process of change, which is still referring to the action plan.

For the Evaluation steps the researchers see the chance to do the reasoning towards the three Regional Banks through the obtained data from the customer, staff, and the division/manager of the Regional Bank, this research does a study to see the changes reached by the Regional Bank referring to the RBA recommendation in the financial and non-financial perspectives until the year 2013 which can be seen in the following description.

\subsection{Core Capital}

The Core Capital of the Regional Bank shows significant changes because the Regional Bank does the Capital source development, which formerly the activity of the Regional Bank dominantly managed the regional government fund, developed with the ability to manage the fund resources from the society, so it can be seen that the average of the Core Capital in 2010 was still under 1 Zillion Rupiah. On the way until 2013 it can be seen that the core capital can 
develop variously to each Regional Bank with the amount between $>$ Rp. 1 Zillion $-\leq$ Rp. 5 Zillion. The variety of the amount of the core capital is caused by many factors including the variety of attention given by the regional government, Regional Bank which gets more maximum attention from its regional government shows that is a significant capital addition, different with the Regional Bank where its regional government has not given maximum attention. It can be seen from the other side found that the Regional Bank which becomes the real sample has been able to sell the stock to the society (go public). This condition shows until 2013 the Regional Bank has been able to increase the Core Capital as the RBA recommendation which is more than Rp. 1 Zillion.

\subsection{The Quality and Competence of Human Resources}

The quality and the competence of the Human Resource, the Regional Bank with all of the awareness understands the still not maximal quality of Human Resource, so the Regional Bank can use the available Human Resources more optimal with the quality based on the market standard, the Regional Bank adapts the performance of the Human Resources with the demand of the environment change that happens fast in every fields and continuously. This situation needs to be anticipated by increasing the quality and competence of the Human Resources owned by the Regional Bank starts from the low level until the high level. The Regional Bank make various programs which are the Human Resources development program, the working culture development program by doing the induction program, technical competence training, attitude competence training, leadership career training program periodically, which are done equally depend on the working needs/the position of the Human Resources in the Regional Bank. The changes of accomplishment, based on the statement made by the staff of the program implementation shows that $70 \%$ of the Regional Bank staffs stated that they were participated in the training based on the work and continuously so they can feel improvements of their skills while working, and have a better ability in giving response to the customer, it also is admitted to be able to bring out the hidden potential along the time. With the training and developing program, the workers' performances increase. Besides the programs done internally the workers stated that the increase of the knowledge is related with the banking nationally. This result shows that the RBA recommendation in the dimension of the quality and competence of the Human Resource can be applied.

\subsection{The Innovation and Development of The Product}

The Innovation and Development of the product, the Regional Bank keeps trying to increase the competitive advantage of the products and services offered by developing the features of the product in various types of savings, deposits and credits. Until year 2013 there has been a condition that shows the developing interest of the society in the products of the Regional Bank, this improvement can be reached through the best products which are savings, deposits and credits. The Regional Bank can offer the products with competitive administration fee, and with a cheaper price compared to the National Bank. The Regional Bank has also been able to give a competitive interest, and a low initial deposit, besides the ability of the Regional Bank to increase the competition through the ATM with various features beside the 
banking transaction can also used as the easy tool for the customers that can be functioned as the payment tool, the money transferring tool whether the transferring to the same bank or different bank. As the form of the Regional Bank caring to the environment demands, which see there is a market opportunity in managing the finance which is based on the Syariah system, to fulfill the society wishes in the region where the Regional Bank offers the Syariah units. The other forms of product development are shown through the care of the Regional Bank towards the needs of the society in rural areas to run a micro business, the Regional Bank launches credits without warrants, which prioritizely given to the small businesswomen and is distributed in groups. The Regional Bank has a network with the finance institution called People's Credit Bank (PCB)/Bank Perkreditan Rakyat (BPR). The Regional Bank is also expected to be the Apex Bank which functions as the Central Bank for the PCB. Until recently, there is only one Bank that can run this role that it becomes the example for other Regional Banks, it is Jatim Bank. As the Apex Bank it has a system called Jatim Electronic Transfer System which helps the PCB in doing the bank clearance, and it also has trained $92 \%$ PCB in its region. And it has been able to give on-going fund for the trained PCB. Besides it is related to the financial, the training for the PCB is also done through the education and training.

\subsection{The Office Network Service}

The office network service, to introduce the product and service of banking especially to the society in rural area, and the society in particular area, until 2013 the Region Bankcan do a network expanding until sub-district area. From the plurality network perspective such as branch office, branch offices, cash office and cash car shows that the significant development is happening. The development of Branch Offices can be seen from the existence of the number of the Cash office from 78 offices in 2010 increase to 120 offices in 2013. For the Cash office in 2010 there are 154 offices increase to 176 offices in 2013. Besidesdeveloping the offices, the Region Bank keeps trying to introduce the service and product until it reach the society in rural area by creating the Cash Car for reaching the people in isolated area as the target, and also to use the chance from the citizen which has limited time to visit the branch office or other Cash office, the Region Bank is ready to pick up the 'ball' by using Cash Car visiting the market, school, and university or the particular Office. The number of Cash Car in 2010 is 19 units become 23 units in 2013. Besides doing the network development, Region Bank also develops the network by using the electronic facilitate as the development in Technology Information Region Bank, which can give the easiness for the people nearby the ATM area, network service of ATM Machine develops fast. We can see in 2010 the number of ATM is 151 units become 233 units in 2013. Besides Region Bank ATM has had the capability in Electronic Banking (E-Banking).

\subsection{Brand Awereness}

Brand Awareness Region Bank, in 2010 still shows the weak competition that can be shown by the decreasing of interest on product or service that is offered by Region Bank, along with the effort doing organization and the change of management, the previous Region Bank is called as The Regional Development Bank. Until 2013, The Region Bank in Indonesia no 
longer uses the name 'The Regional Development' change become Bank Sumut, Bank DKI, and Bank Jatim. From the physical appearance of the previous Region Bank is white and now has changed become the brighter color which symbolize warmth and spirit. Beside that the using of product and service of Region Bank shows the number is still increasing significantly, this improvement can be investigated from the result of Questionnaire which is given to the Customer, some statements are obtained as the reason why do they become the customer in this Region Bank those are the customer admitted that they can choose the product based on their needs, because Region Bank could offer the various products, in service field, the customer stated that the Staff of Region Bank can allocate the service time well, in the other hand, Staff of Region Bank can show the attitude and behavior in giving information about new product clearly and well, the customer feel the opportunity that is gained by the used product and also in the interaction among the customers can feel that there is a good relationship with the staffs, the other things that stated by the customer that the Region Bank shows the attention to the customers about either suggestions or complaints. The illustration of this condition become a realization Repositioning corporate Image of Region Bank, which can be seen from the "Award" which gives the assessment to Bank Performance nationally in Regional Development Bank category.

For the adoption step which is the step of using changes, which is followed by the activity, make sure the thing that had experienced the changes, in doing the activity whether it has totally changed or not, this condition needs to be understood because it will be a commitment to be done based on the changes. The process of changing of Region Bank has not done the adoption step yet because the period of time which is recommended by RBA will be ended in 2014.

Separation, from the interview which has been done with the manager of Region Bank, stated that the recommendation which is stated by RBA for 2014 not all of it can be real, there are some perspectives which is recommended by RBA which had felt by the Region Bank still hard to be achieved, especially in financial perspective, this condition had been discussed in the meeting of Region Bank nationally, in 2014, with the agenda will revise the recommendation in 2014. This is the confession steps of Region Bank in the accomplishment productivity possibilities which is better by doing the other steps, and also see the possibility to do a consultation contra-productive in making changes.

From the accomplishment, it can be stated that the Region Bank had done the development and revolution. From the variants data that had been taken, the understanding based on the right data is the important factor, this appropriateness can be seen from the result that had been achieved. The data obtained from the Regional Bank is able to show the suitable result for example the data related to the Human Resources, there is a suitable result with the result shown from the staffs' statements related to the competence. Besides the success achieved, there are still RBA recommendations that have not been able to be implemented, from the two conditions found the decision maker is expected to be able to set the effectiveness of the changes intervention, if the intervention finds the purpose of the organization development, then the development process can be done, which is shown through the increasing organization graph, in contrast if the intervention has not been able to find the purpose of the 
organization development the next step is whether to continue the cycle by making plans and deciding new intervention, or it is stopped. From the interview/focus group discussion with the heads of the Regional Bank, it is admitted that there are still recommendations that have not been implemented, based on the interview result with the heads of the bank, the condition that will be made refers to the steps of continuing the intervention as the evaluation result that will be made previously.

\section{Conclusion and Implication}

The practice of the organization's development to the Region Bank that has been adjusted with the characteristics of the organization development (Mc lean, 2005), which The Region Bank can align between the organization and the purpose of Region Bank business as the finance institution in the region with the goal to be the bank that is praised by the society in its region based on the behavioral knowledge, the process of development that is implemented by the Region Bank based on the knowledge which can be viewed from the behavioral knowledge such as the management of human resources knowledge, the behavioral of organization knowledge as a knowledge that is implemented to know about the training and development of competency program, and the behavior of the organization members, for long period and continuously, the development of Region Bank process is an on-going process from 2010 until 2014, this research refers to the data in 2010 until 2013, it emphasizes the orientation process to achieve the result, the demand of the development process of Region Bank is to reach RBA recommendation until year 2014 based on collaboration which is an orientation system. The changes of the Regional Bank process are based on the collaboration from many elements on the Regional Bank with the orientation system. The changes which appropriate with the necessity of the Regional Bank is an expectation which is to be a commitment of the manager of Regional Bank and also the other members, because the steps which are implemented in OD will be determiner the Brand Awareness in Regional Bank, besides it is to be the bank that is praised in its region, because it is able as the development of economics' activator in each region and also be able to become the front guide of the region development's economic, and also it has the capability to compete in The Asean economic society.

\section{Acknowledgement}

This research is financed by the fundamental fund from the Indonesian Directorate General of Higher Education, Ministry of Education and Culture. Special thanks to the Director of Society Research and Service.

\section{References}

Amin. Z. A. (2012). Enam BPD Masuk Nominasi BPD Regional Champion, www.tempo.co

Asbanda, (2010), Memperkuat Daya Saing dan Kelembagaan Bank Pembangunan Daerah (BPD sebagai Regional Champion),www.asbanda com. 


\section{Macrothink}

Journal of Management Research

ISSN 1941-899X 2015, Vol. 7, No. 2

Beckhard, (1969), Organization Development : Strategies dan Models", Reading, MA: Addison - Wesley

Cummings \& Worley.( 1997). Organization Development and Change” Sixth edition, South western Publishing,

Cumming's T.G., Worley C. G. (2009). Organization Development \& Change, 9th edition, South Western Cengage Learning, USA p.

(2014). Health Behavior and health education, Theory, Research, and Practice, www.med.upenn.edu)

McLean.G.N. (2005). Organization Development, Principles, Processes, Performances, Barret Koehler

Neilsen. ( 1984). Becoming an OD Practitioner, Englewood Cliffs, C: Prentice Hall, p.2

Rouda,R., H., \& Kusi, M., E. (1996). Organization Development The Management of Change, www.alumnus. Caltech.edu

Sulivan,R,W,R, \& McLean,G. (1995). Model for Change and Steps in Action Research, in Practising OD: A Guide for Consultants, Pfeiffer, San Diego,

\section{Copyright Disclaimer}

Copyright for this article is retained by the author(s), with first publication rights granted to the journal.

This is an open-access article distributed under the terms and conditions of the Creative Commons Attribution license (http://creativecommons.org/licenses/by/3.0/) 